\title{
TFF3 Gene
}

National Cancer Institute

\section{Source}

National Cancer Institute. TFF3 Gene. NCI Thesaurus. Code C101769.

This gene is involved in maintenance of the intestinal mucosa. 